\title{
Cannibals in Paradise The Exotic, the Familiar, and the Strange in Ritual and Performance in Vanuatu
}

\author{
HUGO De B L OCK, Royal Academy of Fine Arts, Ghent, \& University \\ of Ghent, Belgium. Email: Hugo.DeBlock@UGent.be
}

\begin{abstract}
Within a framework of politicized revitalization of culture, conceptions of "the real," of authenticity, are omnipresent in Vanuatu. Ancient ritual is reenacted in cultural festivals that take place in several locations throughout the archipelago in a context of cultural revival as well as tourism. Based on fieldwork in Vanuatu in 2008-2009, in this paper I discuss the encounter between the self-declared primitive and the tourist. In a bricolage of ritual that is put on, both the strange and the familiar intervene, in the form of cannibal — as well as paradise-imaginaries. In most islands, this results in different ways of knowing and different discourses, which in turn generate discussions among local people about what it means to revive culture. People negotiate notions of "the real," of the authenticity of their actions, and disagree about whether their culture is familiar or strange to themselves while at the same time offering it to outsiders.
\end{abstract}

Key words: anthropology, art, performance, revival, tourism, Vanuatu

In contemporary Vanuatu, in the Southwest Pacific, culture is a big thing. ${ }^{1}$ Kastom, kalja, and tredisin (custom, culture, and tradition, respectively) practice and discourse are rooted in the cultural revitalization movement in the archipelago, which in turn is rooted in a long-standing tradition of politicized kastom uses. Emerging in the context of colonization and missionization of the late nineteenth and early twentieth centuries, kastom was from its beginnings an oppositional concept. It was an alternative to skul, or Christianity (cf. Bolton 1999; Rousseau 2011). ${ }^{2}$ It is in these lines that "cannibals in paradise" operate, between the familiar and the strange. Or, as Marianna Torgevnick has put it, "'savages' and 'cannibals' — or at least the way in which they are imagined - exist for us in a cherished series of dichotomies: by turns gentle, in tune with nature, paradisal, ideal—or violent, in need of control; what we should emulate or, alternately, what we should fear, noble savages or cannibals" (1990:3). For Vanuatu, particularly by the time of independence in 1980, when the Anglo-French Condominium of the New Hebrides became the Republic of Vanuatu, and in the years following, culture and kastom discourse accelerated and became a vehicle for unification of the nation-state. The First National Arts Festival of 1979 was an important in-

Submitted March 20, 2017; accepted December 6, 2017; published online October 10, 2018.

Journal of Anthropological Research (Winter 2018). (C) 2018 by The University of New Mexico.

All rights reserved. 0091-7710/2018/7404-0008\$10.00 
centive in this process, described by Lissant Bolton as the pivotal moment "when the country saw itself as a country for the first time" (2003:30).

Meaning and value of culture in Vanuatu is closely linked to intellectual cultural property rights and the reproduction of knowledge, and with its material component, the reproduction, use, and sale of what local people in Vanuatu call artifak, in a context of cultural revitalization as well as commodification and tourism. ${ }^{3}$ An artifak can be a marker of ritual life, but it can also be a commodity. It can be a spoon or a knife. It can be for use, or it can be for sale. It can also be a "high art" piece such as a mask that was used in revived ritual performance. The documented history of the commodification of kastom and the arts begins in the 1960s-1970s, at a time when people who still adhered to kastom were an important minority in the kastom movement as well as in the tourist arena, which was equally emerging in those years. In revived ritual sequences, men dress up to perform aspects of their ancient culture for audiences that consist of local people and paying tourists. To local people, the performance of kastom is only one aspect of their revived culture. Underlying sensibilities, such as who has the right to perform what kind of dance, song, or ritual sequence, are important but do not always surface in these performances. Men dress up in local costume, wearing paraphernalia such as pig tusks and leaf and flower decorations and showing their sexualized male bodies, but, on the local level, they need to link themselves to ancestors who are important in culture history and to indigenous claims for ownership of rituals and objects. For all the performers, the prefix "from an important kastom family" aides them in legitimizing their place within the cultural revival.

Within the social space that is created during performances, local people position themselves in opposition to the tourists for whom they perform. This is exemplified by a clear demarcation space on the commodified ritual ground, in which the ritual ground itself (usually a cleared space in the bush) separates the performers and audiences. Men reenact rituals of the past at cultural festivals, often encouraged or even sponsored by the state, performing their primitive self, wearing the nambas (penis sheath) on a former "dark bush" nasara (ritual ground) or on white, picture-perfect beaches. In the latter case, interpreted as "inauthentic" and commercial-only by the locals, the demarcation between performers and photo-snapping audiences is somewhat blurred. On the nasara, the demarcation stands for a physical boundary only. The opposition between locals and tourists is blurred in all settings in the sense that different mediators are at play between the "familiar" and the "strange," creating not a divide, but some kind of contact zone between locals and tourists. In that sense, the "exotic" is becoming increasingly familiar to tourists and at the same time becoming "strange" to locals. The two meet somewhere in the middle, in discussions among locals and with their audiences that tackle issues of appropriation of culture, resignification, and elevation.

\section{CANNIBALS AND TOURISTS}

At the core of the problem of representation lies the historical dichotomy imposed by the colony and the church between the "cannibal" and his "paradise." Known as the 
Cannibal Isles throughout the nineteenth century, Vanuatu became known throughout the twentieth century as a friendly place for the enjoyment of pristine culture and nature. Whereas missionaries were prone to banish "heathenism" and its "idols," other imaginaries of the Pacific remained exotic, as a tableau of a tribal utopia, an unspoiled paradise. Within this imaginary, the "Melanesian cannibal" remained dark. Clashing imaginaries of "heathen idolatry" versus "exotic," "unspoiled paradise" meet in encounters between ex-cannibals and tourists. Hence is born another opposition, in addition to that of kastom versus skul. Roger Boulay, in Kannibals and Vahinés (2000), unravels part of this dichotomy. The cannibal in his title refers to the fierce Melanesian cannibal of the past, always male, whereas the vahiné refers to the Pacific belle, a Polynesian, ukulele-playing, bare-breasted maiden: an opposition between the Melanesian male, dark and man-devouring, and the Polynesian female, fair-skinned and voluptuous, or an opposition between "dark bush" (Abong 2008) and the beach. Yet, male and female were imagined to be part of one and the same culture in all sorts of adventure literature, photography, and film.

For Vanuatu, the best known "dark" example is depicted by Martin and Osa Johnson in their movie Headhunters of the South Seas (1922), in which they present their protagonist, Big Man Nagapate of the Big Nambas tribe of Northeast Malakula (Figure 1; Imperato and Imperato 1992; Lindstrom 2006). The French production Chez les Mangeurs d'Hommes, released in 1931, was also shot on Malakula and intended to showcase "the last cannibals." This film even included a mass reenactment of a cannibalistic scene. In the 1970s, David Attenborough shot an episode of the documentary series The Tribal Eye on Malakula, featuring a ritual ground, a men's house, a performance of puppets of the long-defunct nevinbur "secret society" (Deacon 1934:461) and, as the highlight of the film, a group of rambaramp effigies containing the skulls of ancestors lined up inside a men's house, all filmed and explained by Attenborough on location as if nothing had ever changed. One of the effigies, reportedly, was bought by Attenborough's cameraman after filming (Kevin Conru, personal communication 2011).

In the documentary film L'île Noire, released in 1998, next to the usual authoritative voiceover, "the native" for the first time had his own voice. This film, shot in North Ambrym, tells the story of Johnson Koran, my adoptive father in Vanuatu since 2008-2009, going fishing in his outrigger canoe in the 1990s. The moralizing story tells of Johnson, who is unable to catch a fish. He decides to ask Tofor of Fanla, considered by all to be the last legitimate Big Man for the area, for advice. On our way to Tofor, we witness the felling of a tree by a group of men and, a bit further, an older man carving a slit drum out of a tree trunk. Once arrived in Fanla village, Tofor, who was Johnson's brother-in-law, blames Johnson for not fishing in the kastom way. This, Tofor says to the camera, is the reason for his meager catch. The film concludes with Johnson making offerings to Ambrym's volcanoes in the center of the island, resulting in a successful fishing trip by using materials in the kastom way. In the film, Johnson and Tofor speak Rral (North Ambrym language) and Bislama (Vanuatu pidgin). John- 


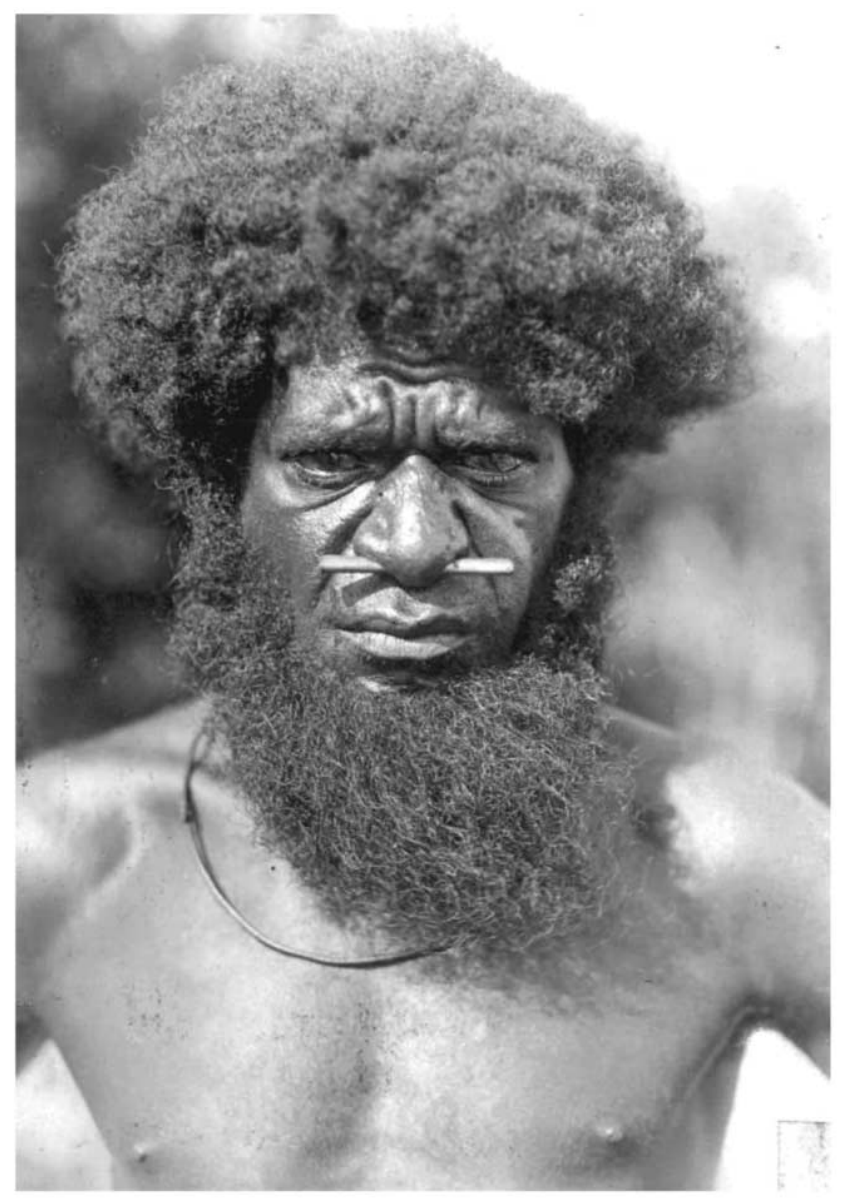

Figure 1. Nagapate, 1917 (C Martin and Osa Johnson Safari Museum, reproduced with kind permission).

son, who also speaks fluent French (he was a police officer for the Gendarmerie Française during colonial days), acted as his own translator (but was not credited for this in the film) while at the same time presenting himself in the film as an insecure man who had left kastom. During the film we see the highlights of the island of Ambrym: the kastom village of Fanla, the last undisputed Big Man for the island, the worldrenowned Ambrym-style slit drums or atingting exhibited in museums worldwide, and the volcanoes.

Today, romanticized images are widespread on the Internet. One example is a photograph on Flick'r of Worwor of Fanla, presenting his exotic primitive self (Figure 2; posted 2009). Comments in response to this photograph include "beautiful light!!! It's a very misterious [sic] portrait!! Is he a warrior?" (by perfectdayjosep) and "this is THE male" (by Stefano Kerberos). 


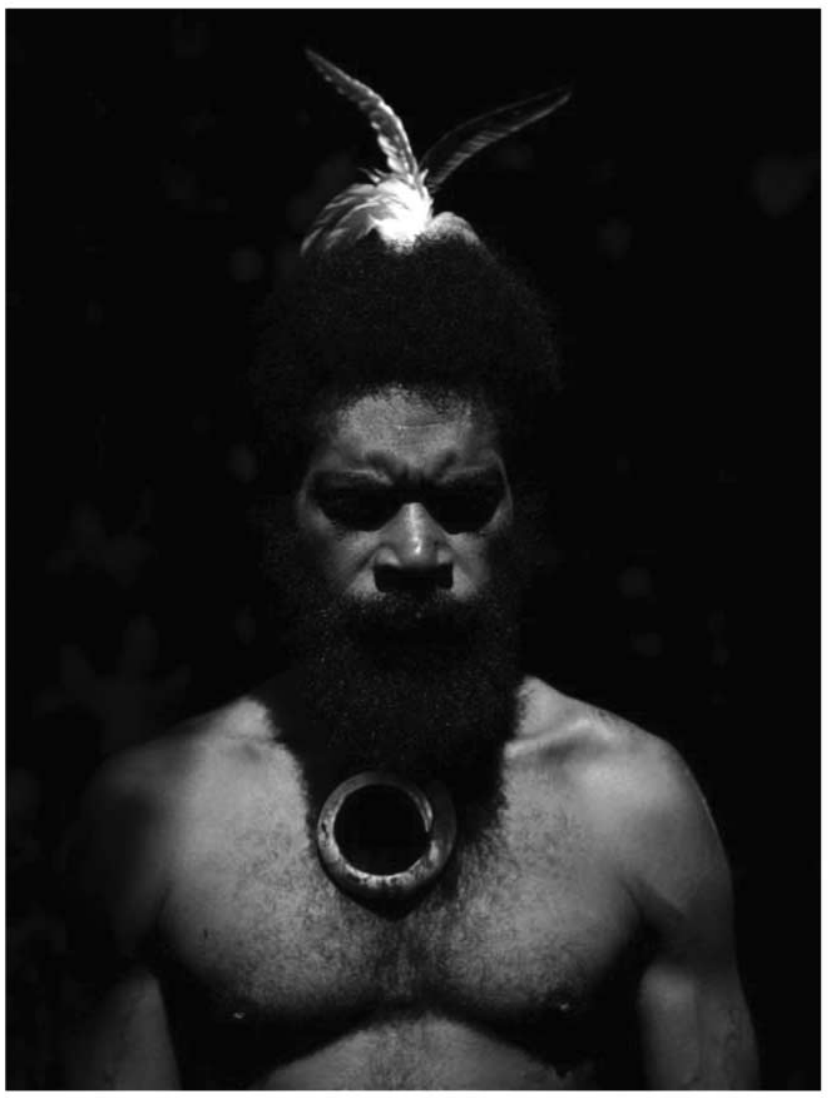

Figure 2. Worwor, of Fanla (C Eric Lafforgue, on Flick'r, 2009)

For Vanuatu, only recently, accompanying the development of tourism, has a paradise discourse parallel to that for Polynesia developed. "Vanuatu, The Unspoiled Paradise" is now a popular slogan in all sorts of tourism-related promotional materials and even in daily speech among locals. Updates on additions to tourism options are also regularly reported in the "What's on" section of the Vanuatu Independent (e.g., "Tourism Opens Up in the Banks" [4 March 2007], "Paama Has Bungalow: First Stop on Road to Tourist Mecca" [29 April 2007], and "Southwest Bay Yacht Club Opens" [21 September 2008]). Events such as Tok Tok Vanuatu, organized by the Vanuatu Tourism Office, are held regularly to attract tourism brokers and wholesalers, and numbers of participating brokers and travel agencies are growing (Vanuatu Daily Post, 31 August 2012). In 2007, Toktok Vanuatu was announced in the Vanuatu Independent as follows:

Toktok Vanuatu is a huge event that brings to Vanuatu those who will be selling tickets to this country for a long time to come. We have a vibrant culture, 
beautiful islands and the region's best hospitality. We don't do silly things like organise coups or burn down half the town and we are closer to the larger regional population centres than those who do. Whoever you are, whatever your business or occupation, make the visitors welcome this week. They will surely come back (26 August 2007).

This specific ad illustrates the strong competition with neighboring Fiji, where "silly coups" are held and towns are half burned down, and which, furthermore, is farther away than Vanuatu when it comes to the prime customers in Australia and New Zealand.

Although many of the smaller tourism alternatives, organized at the grassroots level, are unsuccessful and do not last long, it is becoming increasingly clear that locations in Vanuatu such as Champagne Beach on the island of Espiritu Santo or the white sandy beaches of the Banks and Torres Islands in the extreme north of the archipelago are catching up with their dark volcanic neighbors, Malakula and Ambrym. On Malakula and Ambrym, commodified ritual performances are continuously organized for audiences on dark-bush-enclosed nasaras, but places such as Champagne Beach are becoming more and more popular among Australians and New Zealanders as holiday and destination-marriage locations, and in the Banks and Torres Islands different dance troupes are increasingly organizing performances, showcasing sexualized bodies in sunny, white, and sandy beach locations. The "differences" between these kinds of sites are sometimes spelled out by visiting tourists and taken into consideration by locals. In 2009, while I was at an annual festival in North Ambrym called Back to My Roots, some tourists came up to me to talk about how wonderfully grotesque these performances were in comparison to those in Polynesia; that these masked men, dancing in circles and closing in on each other in the dark, were the exact opposite of Polynesian bula girls dancing in welcoming ways with their arms open, or the dancers on the white sandy beaches of Espirito Santo and the Banks and Torres islands. ${ }^{4}$ Some of the Back to My Roots dancers were worried about this remark and wondered whether they should regroup and perform on the beach in the future, but most of them realized that presenting themselves as dark, fierce males was exactly why they too were successful. Their success lies in their "former-cannibal" imagery, with a smile.

\section{KASTOM AND TOURISM}

On one level, "the native" enacts himself in order to cater to the market principles of supply and demand, what Nick Stanley (2007) and Charles Lindholm (2008) have termed auto-exoticism (after Joep Leerssen), or the exoticization of one's self. Worwor of Fanla, for example (see Figure 2), was not just exoticized by another, he also exoticized himself by posing in the way he did for the camera. Jean and John Comaroff, in Ethnicity Inc., have defined such individuals, such entrepreneurial "natives," as ethnopreneurs (2009). Exoticization, moreover, relates to sexualization. Lamont Lindstrom, in "A Body of Postcards" (2007), provides an overview of "natives" imagery for Vanu- 
atu with a focus on the sexualized male body, from Nagapate, the chief immortalized by Martin and Osa Johnson (Figure 1) to the particularly (homo-)eroticized body of a young man from the island of Pentecost, wearing the penis sheath as well as a hibiscus flower in his hair (traditionally a marker of male power), carrying a club over his shoulder, loosely, in dandyesque fashion, posing for the camera (in Bonnemaison 1980, photograph by Bernard Hermann). ${ }^{5}$ Lastly, auto-exoticism also relates to ritual and performance. In relation to the Chambri of Papua New Guinea, Deborah Gewertz and Frederick Errington noted that "if they continued to sell their initiations (and perhaps other ceremonies) as tourist attractions, they would themselves no longer find them convincing and effective" (1989:51). Drawing on Gewertz and Errington, Nick Stanley added: "once a gap has been created between lived experience and the account of such experience a sense of unreality creeps in" (2007:12). "The account, the performance, comes to become utterly self-conscious and exotic" and it is "a meaningless muddle" (2007:12). "The very self that is displayed becomes an alien presence, never to be fully captured. This, in turn, leads to the second process, the loss of belief" (2007:12).

On another level, local men are proud to relive their rituals of the past, their ancestral ways. A performance or an object that features in such performance has monetary value (it is made for sale, or not made for sale but sold anyway), but it can have other sets of values (Graeber 2001) attached to it, outside the realm of the commercial, such as a family history, pride in one's culture and artifacts, artistry and craftsmanship, acknowledgment of indigenous ownership, or connection to the (copy)right to make and sell a certain kind of item (again). Wearing the paraphernalia that were once signs of status and prestige gives pride to the wearer and sometimes, when the rules and regulations of kastom abide, renewed status and prestige. When, these days, formal copyright legislation as outlined by the state in the Copyright Act of 2000 (see Geismar 2003, 2005a, 2005b) is increasingly transformed and transforming, in order to fit the needs of some locals, this is done specifically to breach the limits and limitations of ancestral kastom and copyright (kopiraet in Bislama), particularly on the islands of Malakula and Ambrym, which are important islands both in the history and in the contemporary revival of ancient kastom and places where kastom is also business. Copyrights of performances and objects are now stretched to be saleable, just as performances and objects were sold in a system of "ritual commerce" between the islands and between locals in the old days (for discussions on the concept of "ritual commerce" see Bonnemaison 1996; Huffman 1996; Patterson 1981, 1996, 2001). ${ }^{6}$ Haidy Geismar's initial work on indigenous copyright in Vanuatu dates to 2003. The bulk of my work was later (mainly 2008-2009), at a time when indigenous copyright in local settings (Malakula and Ambrym) was rapidly changing and adjusting to new (market) conditions. In recent years, a second kind of indigenous copyright emerged, often referred to as a tu kaen kopiraet (second kind of copyright). This second kind of copyright has developed since 2000 and is locally also translated as "the right to make copies," in which copies stand for actions, knowledge, and things "made for sale only," aiming not to interfere with ancient, sacred kastom. 
One account of an event at precisely such an interstice is by Christopher Tilleynamely, of a dance performance for cruise ship tourists on the tiny island of Wala. He describes it as "an empty vessel of tradition, form without sentiment" (1997:81). He separates dance from mythological structure and cosmological beliefs. Dancers sell their bodies, he writes, in some sort of parody, a theater (1997:81-82). "By constructing a bricolage of different elements from different sources," however, they are also "true followers of 'ancestral ways'" (1997:84). Following in the footsteps of their ancestors who took part in the system of ritual commerce between the islands, he adds, selling culture to tourists rather than to neighboring Atchin islanders "is merely an adaptation to the exigencies produced by global modernity" (1997:84). In this process, the self-declared "native" takes charge. The presupposed gap is closed when all concerned, performers and audiences, realize, as Edward Bruner has so rightfully pointed out in relation to the African context, that the ethno-preneurial "native" who is reviving his past is not living two realities, or a back and a front scene of performance (see, originally, MacCannell 1976), but in fact one complex reality, in which he combines all aspects of this reality (Bruner 2005:5). After all, as Bruner notes, being critical of MacCannell's front and back scenes of culture and performance, all so-called tourist performances are also "real," and back and front engage and are, finally, uplifted (2005:5). Discussion of "the authentic" is only necessary when producers and consumers talk about these issues themselves (2005:5). In Vanuatu, these kinds of discussions surface in the form of disputes among locals and with audiences about what (the revived kind of) kastom is or should be, resulting in the development of different kastom discourses in different places. For example, Southeast Malakulans today refer to the Ambrymese and specifically the North Ambrymese as "stealers of kastom." "They stole our tamtam design," it is said, "and are since making big money with it." It is only in recent years, with copyright nomenclature being transformed and transforming at an accelerating pace, that flexible mutual grounds of communal, shared cultural commerce are not met as often anymore.

A possible way out of dispute and disagreement among locals and with audiences concerning the performed kind of kastom is negotiated on "meeting grounds," such as dark bush ritual grounds in the islands. One such ritual ground is Halhal Fantor in North Ambrym, which serves as the performance ground for the annual Back to My Roots Festival. It is in this kind of performative kastom that extraneous, so-called modern additions are excluded. This kind of performance has also often been referred to as frozen in time and place, unchangeable (e.g., Gewertz and Errington 1989; Stanley 2007; Tilley 1997). And it is this kind of performance that seems to pose problems and in fact is at the forefront of some of the fiercest local disputes concerning copyright and the right to perform a certain kind of dance or reproduce a certain item, or perform a dance or a song in a right or a wrong way. In the islands, although people identify as part of the same community, opinions differ greatly about this revived, performed kind of kastom. People who join in revival are often being judged by their neighbors and family members. A remark often heard is that those who join in revival are only in 
it "for the money," and that the "true" kastom, sometimes even referred to as "authentic" by the locals, is lost. More than in the islands, where "native" ethno-preneurs operate, several dance troupes in the main urban center of Vanuatu now challenge what is considered by all the unchangeable kind of performative kastom in new and innovative ways while remaining careful not to misappropriate their neighbors' and family members' kastom. The best example of such a performance troupe is that of the Vanua Fire group of young, urban performers, male and female. I now turn to this and to a discussion of the Vanua Fire Show performers, who perform on Friday nights at Mele Beach Bar, on the beach not far outside Port Vila town.

\section{BACK TO MY ROOTS AND THE VANUA FIRE SHOW}

In Vanuatu's urban setting, in the capital town of Port Vila on Efate Island and, to a lesser extent but quickly evolving, in Luganville on Espirtu Santo, different kinds of tourism options are at hand. Particularly in and around Port Vila, hotels and resorts cater to tourists along with car rental companies, scuba diving and parasailing schools, and so on. Scenic helicopter flights over Efate are another recent addition. Some tourists partake in the more adventurous things on offer, such as hiking the Millennium Cave on Espiritu Santo, diving Million Dollar Point and the SS President Coolidge just off Southeast Santo (promoted locally as "the world's most accessible shipwreck"), or climbing Yasur volcano on the island of Tanna (promoted as "the world's most accessible volcano"). Next step up the adventure ladder are the (fewer) adventurers who visit the outer islands on their own, sleeping in village bungalows under a thatch roof. It is particularly these tourists that make it to local cultural festivals on islands such as Malakula and Ambrym, where local people, as I have shown, compete in offering their kastom for audiences (Figures 3 and 4). They charge entry fees at their former sacred sites and sell the paraphernalia of their rituals after use, while tourists and museum and gallery curators consume and compete among each other. In parallel, for Port Vila, the most popular marketing of culture consists of many different shows that are put on for tourist audiences, modeled after the cultural festivals in the outer islands, sometimes inside hotels and resorts but often outside, on the beach. ${ }^{8}$ Of these performances, one stands out because it ties in with history as well as with the current urban context: the Vanua Fire show (Figure 5).

Since 2011, the Vanua Fire show has taken place every Friday night at the Beach Bar, on Mele Beach (Mele is Vanuatu's largest village, a few miles outside Port Vila). Vanua Fire is a free show, showcasing urban youths performing newly developed fire dances. The youths are part of the Wan Smol Bag Theatre group and grassroots NGO. The group's main aim is to create awareness, via its artistic productions, of some of the problematic issues surfacing in contemporary Vanuatu, such as unemployment, alcohol and drug abuse, domestic violence and violence against women and children, prostitution, the first AIDS cases, and so on. Particularly through film, their messages get spread widely over the islands, with local Wan Smol Bag staff regularly visiting some of the remotest outer island locations to increase awareness of pressing issues of the 


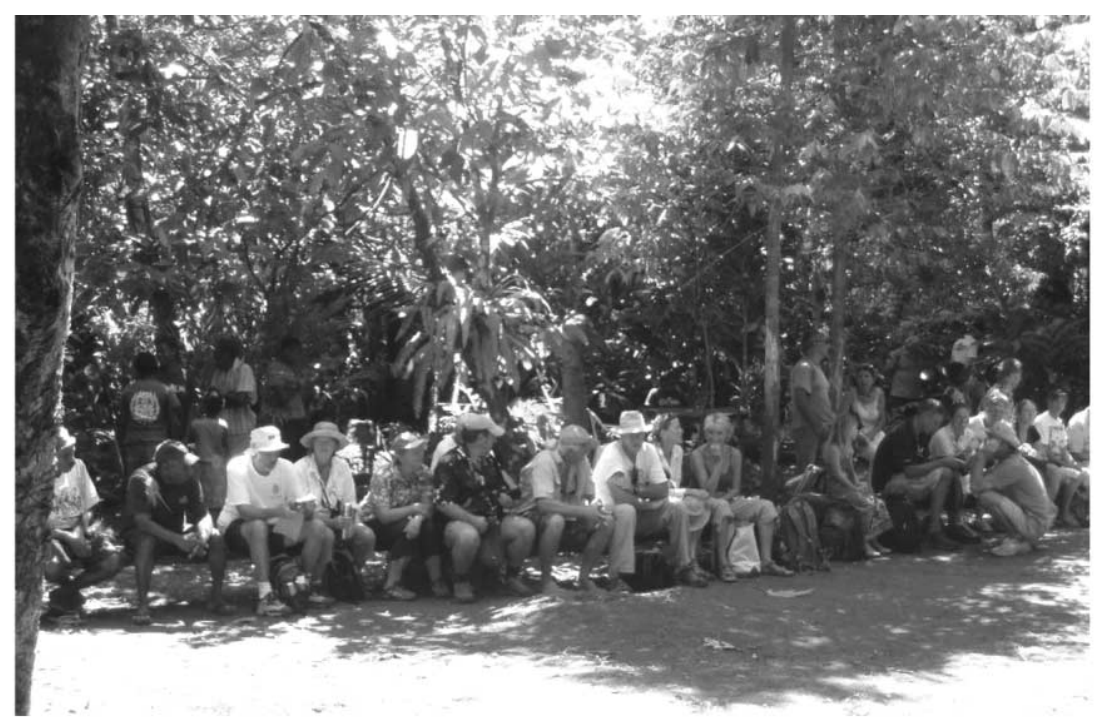

Figure 3. The audiences at the annual Back to My Roots Festival, Halhal Fantor, North Ambrym, August 2009 (photograph by Hugo DeBlock).

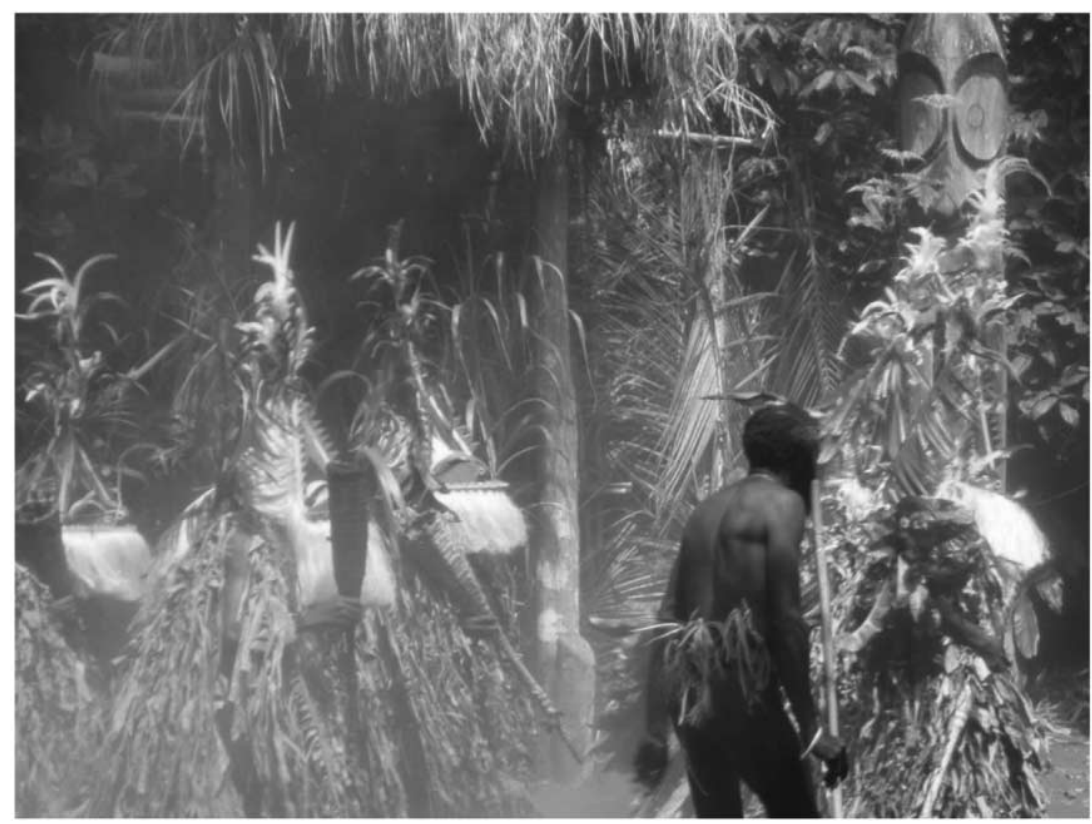

Figure 4. Performance of masked dancers during Back to My Roots, Halhal Fantor, North Ambrym, August 2009 (photograph by Hugo DeBlock). 


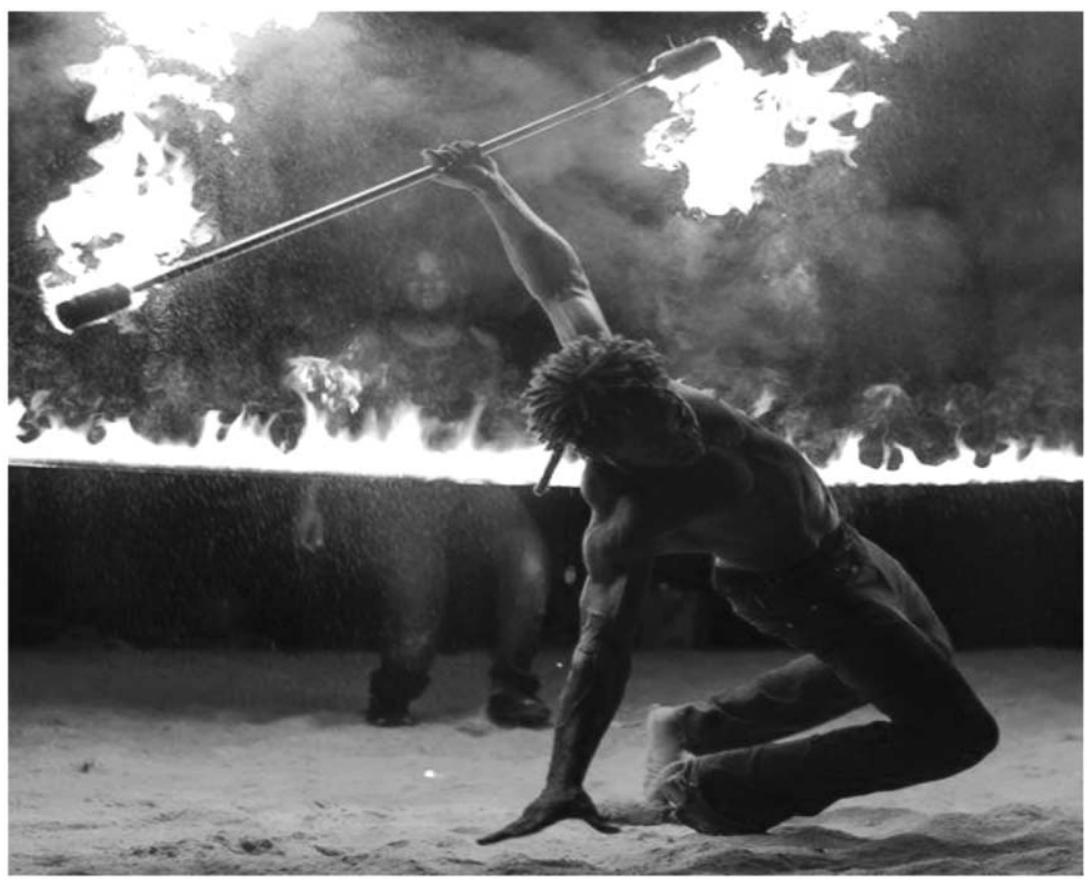

Figure 5. Vanua Fire dancer at Mele Beach Club (@Wan Smol Bag Theatre, reproduced with kind permission)

moment. For example, their film Pacific Star (released 1994) unpacked some of the problems that came with cruise ship tourism in outer island stops. A later film, Wan Tru Paradaes (A True Paradise, 2006), also focused on tourism development in a fictitious remote place within the archipelago. In this film, a local actor played the lead role of a local chief who is corrupted by the tourist dollar, misleading his fellow villagers and keeping the profits of tourism development in his village for himself. In the film, he is exposed as corrupt, and the people of the village win. It is a story that resonates with actual circumstances on the ground, with many disputes in local places over the meaning and value(s) of cultural revival and over who owns what of culture.

It is precisely at this intersection that Vanua Fire, as a performance, bridges some of the existing gaps. Vanua Fire is a contemporary phenomenon, in the sense that what is brought to the fore is a group of young, urban, hipster Rastafarians who identify with diasporic black culture and with whom they call the first black-Pacific president of the United States of America, Barack Obama. Many of these youths do not belong to island-home communities. Many of them, born and raised in Port Vila, cannot claim any island land. As members of a new, emerging urban youth culture, they dance to the beats of contemporary world hits such as "Moves like Jagger" by Maroon 5, and they have a popular Facebook page on which they regularly post photos. On the other hand, in Vanua Fire performances, they quote Vanuatu history and 
ritual in some of their movements, while remaining careful not to copy any dance or ritual sequence exactly, thus staying out of the many disputes and arguments surrounding indigenous cultural property and copyright among local communities. Some of the dances are accompanied by traditional instruments such as slit drums, or the conch shell, and movements and music are made, as in kastom dancing, by stamping with their feet in the sand and wearing anklets. The Vanua Fire show takes place after sundown, which can be a reference to the more secretive aspects of male graded rituals of the past. When compared with Back to My Roots, however, or with the way in which Johnson Koran portrayed himself in the documentary film L'île Noire, or with Worwor's photograph (Figure 2), there is a difference in how these youths present themselves for audiences: their performance forms a part of their search for a new kind of identity in town. They do not necessarily perform for money, but their participation as members of Wan Smol Bag does enable them to earn their livelihood and keeps them off the streets. Vanua Fire combines several imaginaries in creative ways, thus successfully synthesizing current Vanuatu culture with a very rich cultural past.

The Back to My Roots Festival of North Ambrym probably should not be referred to by locals only as stret kastom (straight kastom, the right kind of kastom), as is now often the case, nor should the Vanua Fire show be referred to as kiaman kastom only (liars' kastom, money kastom). In fact, these categories, as do all categories, mix in innovative ways, and the man-made dichotomies dissolve. At the forefront of these mixes are the many disputes revolving around kastom and copyright that negotiate the space created between kastom and commodity. Urban youths in Vanuatu are no different than youngsters in the islands who wish to revive their ancient cultures while earning a livelihood. Urban and island youths want the same thing: to be able to make a living while reliving their ancient and powerful past. Certainly at Back to My Roots, culture, in the form of the mage, a male graded ritual, is performed for tourists and for local audiences, who are proud to see some of their powerful past again. Performances offer a legitimate response to the paucity of means to make a living by selling valued knowledge and objects as commodities as well as an equally legitimate desire to promote kastom. Again, this relates to earlier movements, when ritual and its objects were

traded between different local groups, what is known in the literature as a system of "ritual commerce," with the most competitive, entrepreneurial men and their communities receiving great power and prestige in the traditionalistic sphere.

\section{CONCLUSION}

In contemporary Vanuatu, kastom unites, but it divides as well, as it did in the past (cf. Larcom 1982). What is now left of ancient kastom and kalja are fragments of the vast and powerful ritual complexes of the past in which sacred and secular elements were combined and which consumed a lot of people's energies and resources. The ways in which kastom is brought back is a topic of heated debate and dispute among locals, particularly on the islands of Malakula and Ambrym, where kastom is big business. Ideas and objects continue to hold their validity, whatever their age, as signs and sym- 
bols of kastom and identity and as markers of ongoing cultural relations, property rights, and ownership, albeit in different ways by different people. Those who perform and sell nowadays are being weighed and judged by their neighbors and family members: did they rightfully acquire the right to perform a dance and remake the objects of ritual and sell them? or are they "stealing kastom"? This strategy of commodification of "otherness" requires all "others" to "look other." The authenticity of "the native" equals "cannibals" and "savages," and as a trope this sells in a Western market. Local people exoticize themselves in order to satisfy demand for "the authentic other." They offer their culture as artifact (Kirshenblatt-Gimblett 1998:62) and their wares in created back scenes such as dark-bush nasaras that serve as authenticators for the occasion, lined with artifact stalls. My aim, however, supported by Bruner's critical appraisal of MacCannell's notion of back and front scenes of tourist performances, was to argue that back and front and authenticity do not necessarily define the revival of culture in Vanuatu, but that they mix in creative ways. Within the history of (re)presentation of people and things, via media such as film and photography, "native" imagery was instrumental in identitymaking, past and present. At the heart of this imagery lies the kastom, colony, and church trichotomy as well as the black versus white dichotomy, further problematized by state support for festivals that "return to the past."

But, as always, there are ways out of rigid representation and copyright restrictions. While the "cannibal" discourse, which evolved historically through colonialism and the missions, continues to hold its validity in the context of tourism development, other, competing imaginaries are beginning to resonate back to local communities. "Separate" imaginaries of "cannibals" versus "paradise," or the "strange" versus the "familiar," cater to demands by all involved and by market mechanisms on their own terms, in parallel with supply and demand in the art trade. As we saw, what is "strange" or "familiar" (and to whom) is not always equally clear. The "strange" and the "familiar" are not symbolic categories that define or make meaningful a specific realm of "Self" or "Other," or even a hidden "Other" in the "Self," as the example of "ex-cannibal" and former police officer Johnson Koran in North Ambrym has shown. The same applies to the performers at Back to My Roots, a trial-and-error attempt to retrace and reclaim history and power, without consensus. The Vanua Fire urban youths, on the other hand, quote kastom, but they are careful not to misappropriate anyone's particular kastom; they are finding ways to navigate in innovative and inventive ways around current arguments and copyright disputes. By freely interpreting kastom and kalja, they seem to have found a way past competition and argument and disputes. Vanua Fire is urban kastom of the twenty-first century. The dancers wear their political message of "unity in diversity" on their bodies while dancing, in challenging new ways, as an act of empowerment and self-representation. They uplift the older opposition between kastom and skul and that between the colonizer and the colonized, or "headhunters in paradise." With a new kind of thinking about what it means to revive and live "authentic culture," these urban youths reclaim their paradise for themselves and, in doing so, are increasingly selfgoverning their own future. 


\section{NOTES}

The research project was enabled by various sources of funding, including several University of Melbourne research and study grants. In addition, I received funding for additional research from Goethe University, Frankfurt am Main, where, as a postdoctoral researcher, I was working on the project "Indigenous Museums and Cultural Centers in the Pacific." Finally, the research has been supported by my current position as guest professor at the Royal Academy of Arts of the School of Arts, University College Ghent, and the University of Ghent, Belgium.

1. I carried out long-term ethnographic fieldwork in Vanuatu in 2009, 2010, and 2011, primarily on the islands of Ambrym and Malakula, focusing on the context of value and meaning of cultural revival and production and on consumption of material culture and art, and on cultural festivals and performance. The research was approved by the Vanuatu National Cultural Council. In all field locations, I collected data by way of participant observation and by interviewing people and taking notes, always with the consent of the interviewee.

2. There is an abundance of literature on the emergence of kastom as a political discourse in Melanesia and Vanuatu (most notably Bolton 1993, 1994, 2003, 2007, 2011; Jolly 1982, 1992; Lindstrom 1994, 1997; Tonkinson 1981, 1982). Extensions to women, who are increasingly joining in reviving the past, wearing grass skirts and dancing bare-breasted, were established via the work of Lissant Bolton (1993, 1994, 2003), Margaret Jolly (1994, 1997), and Mary Patterson (2001).

3. The indigenized concept of copyright (kopiraet) has been institutionalized by the state in the Copyright Act of 2000 (see, particularly, Geismar 2003, 2005a, 2005b).

4. For a more detailed description of the annual Back to My Roots festival of North Ambrym see DeBlock 2013.

5. Traditionally part of Vanuatu society, ritualized homosexuality was documented by John Layard (1959) and later Michael Allen (1984). Dean MacCannell referred to homoeroticism as one of three prime characteristics of male "native" imagery in Melanesia, the other two being cannibalism and violence (1992:35).

6. Mary Patterson's work on cultural commerce focused on South Pentecost, Ambrym, and South Malakula, where commerce in ritual and objects "reached its apogee just before the incursions of Europeans in the mid-nineteenth century" (2001:27). Joël Bonnemaison called the region reaching from the Torres Islands in the extreme north of the archipelago to North Pentecost an "Oceanic Mediterranean of influence," a region that was interrelated and interrelating, "throughout which rituals and cultural innovations were constantly being transmitted" (1996:208).

7. Mary Patterson argues that the two styles of slit drums are inextricably linked using a photograph taken by Swiss ethnologist Felix Speiser between 1910 and 1912 in South Malakula and an 1875 watercolor of a scene in Lamap (formerly Port Sandwich), also in South Malakula, showing that what is now widely considered to be the North Ambrym-style drum with elongated head also occurred in South Malakula, at least at that time (Patterson 1996:259-61). Exclusively North Ambrym-style drums 
were collected for the market because these carved drums, with their grand ovoid faces, large chin and forehead, and disk-shaped eyes, were much more "art pieces" than their Malakulan variants, which as a norm only have a truncated top with squat, stylized facial features in low relief (1996:259).

8. On Efate specifically, the push for development has resulted in major problems over kastom land ownership. By 2008, 55\% of all land on the island was leased by foreigners and up to $90 \%$ of all coastal land (Rawlings 2008). By 2011, tourism, after a couple of years of stagnation, experienced a rapid growth (Wittersheim 2011:325). Between 2006 and 2011, a massive increase in the number of cruise ships visiting the archipelago led to a tripling in the arrivals in those years. By 2010, the total number of tourist arrivals in Vanuatu, by air and sea, exceeded one hundred thousand for the first time (in Wittersheim 2011:325).

\section{REFERENCES CITED}

Abong, Marcellin. 2008. La Pirogue du dark bush: Aperçus critiques sur le mouvement Nagriamel au temps des Nouvelles-Hébrides (Vanuatu). Port Vila: Centre Culturel du Vanuatu.

Allen, Michael. 1984. "Homosexuality, male power and political organisation in North Vanuatu: A comparative analysis," in Ritualised homosexuality in Melanesia. Edited by Gilbert Herdt, pp. 83-128. Berkeley: University of California Press.

Bolton, Lissant. 1993. Dancing in mats: Extending kastom to women in Vanuatu. PhD dissertation, University of Manchester.

. 1994. "Bifo Yumi se Samting Nating: The Women's Culture Project at the Vanuatu Cultural Centre," in Culture-kastom-tradition: Developing cultural policy in Melanesia. Edited by Lamont Lindstrom and Geoffrey M. White, pp. 147-61. Suva: University of the South Pacific.

- 1999. Radio and the redefinition of kastom in Vanuatu. The Contemporary Pacific 11(2):335-60. . 2003. Unfolding the moon: Enacting women's kastom in Vanuatu. Honolulu: University of Hawai'i Press.

—. 2007. "Resourcing change: Fieldworkers, the Women's Culture Project, and the Vanuatu Cultural Centre," in The future of indigenous museums: Perspectives from the Southwest Pacific. Edited by Nick Stanley, pp. 23-38. Oxford: Berghahn Books.

2011. "Describing knowledge and practice in Vanuatu," in Made in Oceania: Social movements, cultural heritage and the state in the Pacific. Edited by Edvard Hviding and Knut Rio, pp. 301-21. Wantage: Sean Kingston.

Bonnemaison, Joël. 1996. "Graded societies and societies based on title: Forms and rites of traditional power in Vanuatu," in Arts of Vanuatu. Edited by Joël Bonnemaison, Christian Kaufmann, Kirk Huffman, and Darrell Tryon, pp. 200-204. Bathurst: Crawford House Press.

Bonnemaison, Joël, and Bernard Hermann. 1980. Vanuatu: Nouvelles Hébrides. Port Vila: Editions du Pacifique.

Boulay, Roger. 2000. Kannibals et Vahinés: Imagerie des mers du Sud (préface de Pascal Dibie). La Tour d'Aigues: Éditions de l'Aube, collection Carnets de Voyage.

Bruner, Edward. 2005. "Introduction: Travel stories told and retold," in Culture on tour. Edited by Edward Bruner, pp. 1-33. Chicago: University of Chicago Press. 
Comaroff, John, and Jean Comaroff. 2009. Ethnicity, Inc. Chicago: University of Chicago Press.

Deacon, A. Bernard. 1934. Malekula: A vanishing people in the New Hebrides. London: Routledge.

DeBlock, Hugo. 2013. Back to my roots: Artifak and festivals in Vanuatu, Southwest Pacific. Critical Arts 27(6):768-83.

Geismar, Haidy. 2003. Markets, museums and material culture: Presentations and prestations in Vanuatu, South West Pacific, PhD dissertation. University of London.

- 2005a. Copyright in context: Carvings, carvers, and commodities in Vanuatu. American Ethnologist 32(3):437-59.

- 2005b. Reproduction, creativity, restriction: Material culture and copyright in Vanuatu. Journal of Social Archaeology 5(1):25-51.

Gewertz, Deborah, and Frederick Errington. 1989. Tourism and anthropology in a postmodern world. Oceania 60:37-54.

Graeber, David. 2001. Toward an anthropological theory of value: The false coin in our own dreams. Houndmills: Palgrave McMillan.

Huffman, Kirk. 1996. "Trading, cultural exchange and copyright: Important aspects of Vanuatu Arts," in Arts of Vanuatu. Edited by Joël Bonnemaison, Christian Kaufmann, Kirk Huffman, and Darrell Tryon, pp. 182-95. Bathurst: Crawford House Press.

Imperato, Pascal J., and Eleonor M. Imperato. 1992. They married adventure: The wandering lives of Martin and Osa Johnson. New Brunswick, NJ: Rutgers University Press.

Jolly, Margaret. 1982. Birds and banyans of South Pentecost: Kastom in anti-colonial struggle. Mankind (Special Issue: Reinventing Traditional Culture: The Politics of Kastom in Island Melanesia) 13(4):338-56.

- 1992. Custom and the way of the land: Past and present in Vanuatu and Fiji. Oceania (Special Issue: The Politics of Tradition in the Pacific) 62(4):330-54.

-1994. Women of the place: Kastom, colonialism and gender in Vanuatu. Amsterdam: Harwood Academic.

—. 1997. "Woman-nation-state in Vanuatu: Women as signs and subjects in the discourses of kastom, modernity and Christianity," in Narratives of nation in the South Pacific. Edited by Ton Otto and Nicholas Thomas, pp. 141-72. Amsterdam: Harwood Academic.

Kirshenblatt-Gimblett, Barbara. 1998. Destination culture: Tourism, museums and heritage. Berkeley: University of California Press.

Larcom, Joan. 1982. The invention of convention. Mankind (Special Issue: Reinventing Traditional Culture: The Politics of Kastom in Island Melanesia) 13(4):330-37.

Layard, John. 1959. Homo-eroticism in primitive society as a function of the self. Journal of Analytical Psychology 4(2):101-15.

Lindholm, Charles. 2008. Culture and authenticity. Malden: Blackwell.

Lindstrom, Lamont. 1994. "Traditional cultural policy in Melanesia (Kastom Polisi long Kastom)," in Culture-kastom-tradition: Developing cultural policy in Melanesia. Edited by Lamont Lindstrom and Geoffrey White, pp. 67-85. Suva: University of the South Pacific.

- 1997. "Chiefs in Vanuatu today," in Chiefs today: Traditional Pacific leadership and the post-colonial state. Edited by Lamont Lindstrom and Geoffrey White, pp. 211-28. Palo Alto: Stanford University Press. 
2006. "They sold adventure: Martin and Osa Johnson in the New Hebrides," in Tarzan was an eco-tourist . . and other tales in the anthropology of adventure. Edited by Luis A. Vivanco and Robert A. Gordon, pp. 93-111. New York: Berghahn Books.

. 2007. "A body of postcards from Vanuatu," in Embodying modernity and postmodernity: Ritual, praxis, and social change in Melanesia. Edited by Sandra C. Bamford, pp. 25767. Durham: North Carolina Academic Press.

MacCannell, Dean. 1976. The tourist: A new theory of the leisure class. Berkeley: University of California Press.

- 1992. Empty meeting grounds: The tourist papers. London: Routledge.

Patterson, Mary. 1981. "Slings and arrows: Rituals of status acquisition in North Ambrym," in Vanuatu: Politics, economics and ritual in island Melanesia. Edited by Michael Allen, pp. 189236. Sydney: Academic Press.

1996. "Mastering the arts: An examination of the context of the production of art in Ambrym," in Arts of Vanuatu. Edited by Joël Bonnemaison, Christian Kaufmann, Kirk Huffman, and Darrell Tryon, pp. 254-63. Bathurst: Crawford House Press.

- 2001. Breaking the stones: Ritual, gender and modernity in North Ambrym, Vanuatu. Anthropological Forum 11(1):39-54.

Rawlings, Greg. 2008. Appropriating the corporation, transforming landscape and escaping taxes: The global real estate industry in Vanuatu. Paper presented at the Association for Social Anthropology, Association of Social Anthropologists of Aotearoa New Zealand, and Australian Anthropological Society Conference, University of Auckland, New Zealand.

Rousseau, Benedicta. 2011. "Shifting others: Kastom and politics at the Vanuatu Cultural Centre," in Working together in Vanuatu: Research histories, collaborations, projects and reflections. Edited by John Taylor and Nick Thieberger, pp. 225-39. Canberra: ANU E Press.

Stanley, Nick. 2007. "Introduction: Indigeneity and museum practice in the Southwest Pacific," in The future of indigenous museums: Perspectives from the Southwest Pacific. Edited by Nick Stanley, pp. 1-23. Oxford: Berghahn Books.

Tilley, Christopher. 1997. Performing culture in the global village. Critique of Anthropology 17(1):67-89.

Tonkinson, Robert. 1981. "Church and kastom in Southeast Ambrym," in Vanuatu: Politics, economics and ritual in island Melanesia. Edited by Michael Allen, pp. 237-67. Sydney: Academic Press.

1982. National identity and the problem of kastom in Vanuatu. Mankind (Special Issue: Reinventing Traditional Culture: The Politics of Kastom in Island Melanesia) 13(4): 306-15.

Torgevnick, Marianna. 1990. Gone primitive: Savage intellects, modern lives. Chicago: University of Chicago Press.

Wittersheim, Eric. 2011. Paradise for sale: The sweet illusions of economic growth in Vanuatu. Journal de la Société des Océanistes 133:323-32. 